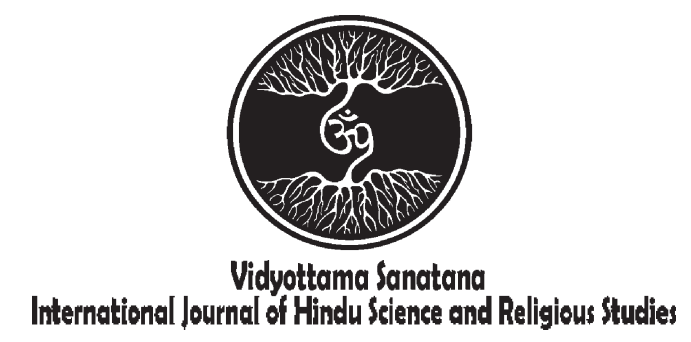

Vol. 1 No. 1 May 2017

\title{
Pedanda Baka Story As Media Of Character Education Since Early Childhood
}

\author{
By: \\ Ni Nyoman Sudiani \\ STAH-DN Jakarta DKI Jakarta, Indonesia \\ e-mail: sudianisstah@yahoo.co.id
}

\begin{tabular}{|l|l|l|} 
Received: October 11, 2016 & Accepted: May 15, 2017 & Published: May 31, 2017 \\
\hline
\end{tabular}

\begin{abstract}
Various media reported about poor child's behavior lately. Some violence committed by children to their own friends, lack of respect to parents and teachers, shows child's bad character. It inspires the writer to dig back cultures that was used as a media of character building for children by their parents long ago. Bali communities has a variety of culture that can be used as a media of character education, such as storytelling culture for children, the story is believed to contain values of character education for children from an early age. The purpose of this paper is to explore values of characters that can be transferred through story of Pedanda Baka and how this story can be used as media of character education to children at an early age. This article is a review of the literature. After assessment, we found that character that can be educated through Pedanda Baka story is religious character. Character education through Pedanda Baka story was done by telling story to children by parents at home and by teachers at school because cognitive development of early childhood is a symbolic behavior, and the story is symbolic. Stories help abstract and intangible concept becomes concrete and tangible. Story can be used as a media of character education since early childhood, because it helps children imitate religious character in the story.
\end{abstract}

Keywords: Pedanda Baka Story, Character Education, Early Childhood

\section{Introduction}

In recent years, media has often reported bad behavior of children, such as: fighting, do violence to a friend, ask for something by forcing the parents, disrespectful to parents and teacher. Some examples of violence that happen in society, such as: an elementary school student was murder by his three elementary 
school student friends in 2014 (online, https:// hello-pet.com, accessed on 20 October 2016), named $\mathrm{J}$, a high school student murder his own classmate named Widian Anggoro teman on 15/10/2016 in Muara Enim, South Sumatera (Online, TribunJogja.Com, accessed on 20 October 2016), and a child who murder his parents because of the parents did not buy him motorcycle (online, Tribunnews.Com, accessed on 20 October 2016). All of those behaviors indicate that child's character is poor. Poor child's character nowadays is due to lack of character education by their parents, because parents today tend to be busy so they have less time to educate character to their child from an early age. In ancient times, based on culture preserved by the community, Balinese educated character to their child through stories told by parents in the bedtime. Storytelling was culture that lives and thrives in society at that time.

Folklore has a very big role in educating character since early childhood because behavior of character in the story can be a role model. Early childhood require figures as their role models. Early childhood tends to imitate behavior of their role models, but if the character in the story is not good, child would not imitate the character. Therefore, parents can use story as a medium to give advice to their children, the impact will be much more visible than without using a story. But this time, most parents had left the habit of storytelling, especially folklore to their child. Early childhood nowadays rarely know various folklores, so that they cannot imitate character behavior from those stories.

The importance of stories for children are also said in International Jurnal that written by Julio E. Correa, Olga B. González and Martha S. Weber (1991) dengan judul "Story telling in families with children: A therapeutic approach to learning problems" said that story telling can be used as an original method to restructure families with children. This paper illustrates how stories can be used in family interaction for treating problems of family origin. Three family cases in which story telling was useful in solving children's disabilities through promoting changes in the family structure and creating or enlightening parental functions of orientation and guidance are analyzed. Furthemore an article that written Pilar Lacasa (2013) by title "Story Telling" said that giving a story to children will make them happy and they can sleep soundly, and an article that written by E. Gal, and others by title "Enhancing Social Communication Through Story-Telling Among High-Functioning Children with Autism (2005)" the result is, the instructions were simplified in order to allow children with communication disabilities to learn and operate the story table. First pilot results are very encouraging. The children were enthusiastic about communicating through the Story Telling and appeared to be able to learn to operate it with little difficulty. Although the research that published uses a different story that the writer use in this study of literature, but these journals can be made as reference in this article.

Based on the concerns of the poor character of early childhood nowadays and low concern of parents to folklores, writers interested to study "Story of Pedanda Baka as Media of Character Education Since Early Childhood" with the following questions: (1) what character education that can be educated through story of Pedanda Baka, (2) how the story of Pedanda Baka can be used as media of character education since early childhood?

\subsection{Pedanda Baka Story}

Storytelling is an ancient art form, before the book is printed; it is the main way that history and culture are preserved and passed on to the next generation (Koster, 2012:376). The same thing also mentioned by Bruce that ancient stories were told orally, long before people write (Bruce 2013:115). Today, storytelling remains an important practice in some cultures, but has been replaced with books. Storytelling 
is also the best way to teach children with special needs. For children who are just starting to talk, the experience of storytelling will cultivate love to story. Storytelling is part of endless child activities. Retell is a model of storytelling by recount stories familiar from memory. Using props, finger movements, and actions, speak with intensity, or using sound to match the characters will help to remember the story and keep kids to focus on the story (Koster, 2012:377-380).

Words in a story can be easily customized for a specific audience, and children are happy when we tell them stories, especially during traveling, it also frees them from the feeling that they cannot read fluently (Bruce, 2013: 116). It is important to speak in the children setting, and the latest research showed the concentrations of speeches and storytelling in early childhood curriculum (Nutbrown and Clough, 2015:237). Nation Advisory Committee on Creative and Cultural Education suggest the provisions of art in formal and informal education for children up to 16 years. Comenius, Rousseau, Froebel, Pestalozzi, and Owen suggest that story telling is important for the development of children. Aesthetics is an important part of child's humanity (Nutbrown, 2015:240). Beckley also argues that story can be used to improve learning and development (Beckley, 2012:75).

There are numerous stories that can be told to children in Bali, each story has its own message. Usually the messages are about love, truth, honesty, and courage, which are part of character education. Story is an effective media of character education for young children, because they love to hear story and still looking for a role model for their behavior. Parents are encouraged to give a good model for their child. One example of folklore that can be used as a media for character education is Pedanda Baka story.

Pedanda Baka is a greedy Crane bird who wants to prey all of fishes in the lake. With a sly sense Pedanda Baka waiting for the right time to to prey all fishes in the lake. Everyday the crane is on the edge of the lake with a sad face that showed to all the fish in the lake. The crane was silent and did not prey on the fishes that swim around the lake, because usually the crane will catch fishes that pass nearby. But the crane patiently hold his wanting to prey on the fishes,so all the fishes will believe in his good intention.showing the sadnnes on crane face,all of the fishes believe and asking about what causes his sadness, finally, the crane said that the pool water will dry up and all fishes will die soon, so he wants to help moving all of the fishes to another lake. All of the fishes believe in him and they are willing to move one by one by one flew by the crane. Pedanda Baka's sly sense Baka finally paid off, all fishes in the lake were successfully eaten, except the crab that was not successfully tricked and have known the wickedness of Pedanda Baka. Finally Pedanda Baka was killed by the crab. The crane called by name Pedanda Baka because he is very good at pretending, he looks good,but incontrary he has bad intent.

Based on the description, can be concluded that a story is a description of an event by using the characters figures in the story as role of a behavior that aims to deliver message that useful for the readers.

\subsection{Character Education}

Tilaar (2009: 1-19) says that education is part of the structure of community life, maturation, and the process of empowerment. Science education is a translation of Pedagogy, Pedagogy which is derived from the Greek word paidagôgeô, which consists of pais, genitive, paidos means children and Ago means to lead, so it literally pedagogy means to lead a child (Danim, 2010:47-49). Education according to Ki Hajar Dewantara is the effort to promote the growth of manners (inner strength, character), mind (intellect) and the child's body carried out in three places, namely: 
family, natural of education and natural of youth movement, and the third is called System Trisentra (Dewantara, 2004:14-70).

Character education is a direct approach to moral education (Santrock, 2009:138). An expression says that moral without intellectual is impotence; intelectual without moral was a disaster (Gotama, 2007:26-27). According to Lickona (1991) education has two major objectives, to help students become smart and help them to be good, so the emphasis of education is focusing on academic standards and educational character (Lapsley and F. Clark Power, 2005:220). Bung Karno, our founding fathers, asserted that nation must be built by giving priority to character building because that will bring Indonesia into a great, developed, prosperous, and dignified nation (Saman and Hariyanto, 2012:1). Character education can be given at any time and in all places, either at home, at school, at work, or during play time, through formal curriculum, informal sector, or through norms (Lapsley and F. Clark Power 2005:221).

Berkwits define character as "simply put, character is comprised of reviews of those characteristics that lead a person to do the right thing or not do the right thing" (Damon, 2002:69), then Booker T. Washington said that character is power (McElmeel, 2002 :xiv), Sri Swami Sivananda define character as inner tendency which makes desire becomes possible (Sivananda, 2003:64). Thomas Lickona said that character is a complete unity between moral knowledge, moral feeling, and moral behavior which are interrelated. Furthermore, Thomas Lickona said that good character consists of knowing good thing, wanting a good thing, and doing good thing (Lickona, 2012:82). Character of Balinese in general was also built by three things, think right, tell the truth, and do right, those 3 character was in unity and interconnected. Mahatma Gandhi said that there are seven crimes or sins committed by modern humans; one of it is knowledge without character (Atmaja, 2010:7).

Character is formed since birth and will evolve with age, and the process of character development is influenced by heredity (nature) and environment (nurture) where the people grow and develop (Santoso, 2011). According to Dewey, character is part of person's essential nature (Kontopendis, 2011: 168). Implementation of character education in Indonesia is based on several grounds: (1) religion, (2) Pancasila, (3) culture, and (4) national education goals (Samani and Hariyanto, 2012:52).

Based on some opinions about the character education of the above, it can be concluded that character education is all efforts made as the process in order to help the growth and development of thinking, feeling, and action learners in order to become a coherent whole as a guide in every act.

\subsection{Early Childhood}

Early childhood according to a scientific study is children from birth to eight years old (Roopnarinen, 2009:3). Another source said early childhood education is education that began from pre-kindergarten through thirdgrade of elementary school (Morrison, 2012:139), and early childhood by Ki Hadjar Dewantara referred to childhood, until the age of 7 years (Dewantara, 2004: 80). Age of the child at this strategic period is often called as golden age (the golden period). John Amos Comenius believed that education should start at an early age, because "young plants can be transplanted, trimmed and shaped, but when it became a tree, these processes cannot be done" (Morrison, 2012:62).

Early childhood grow and develope through the developments, such as psychomotor, cognitive, languabe, social, emosional and moral developments. The child cognitive development feature according to Piaget, at the period of motor cencor is the part of the beginning development, it happen from 
birth time to two years old. In this moment, baby build understanding about the world by making coordinate cencor experience, such as see and listen proses, through motoric systim they develope to touch and reach something (Santrock, 2009:50). The next step is preoperational at the age of 2 to 7 years old based on the Piaget theory divided into two part, first is the part of symbolic function at the age of 2 to 4 years old and second is the part of intuitive thought at the age of 4 to 7 years old. When they are getting older, the symbolic thinking goes to intuitive thinking (Worth, 1995:6). Moral development, Kohlberg said "people passed six series of moral understanding that consist of three level: pre-conventional, conventional, and after conventional. Most of the children passed the stage pre-conventional at the age of 9 years old, (Slavin, 2008:72). At the time of this pre-conventional early year children do not show the moral value. The understanding of morality controlled by external appreciation and punishment (Santrock, 2009:138). Recently, there is a full attention to moral personality, such as: (1) moral identity, a person has moral identity when the moral idea and commitment is an important thing in someone life. If the child's behavior broke the moral commitment, and it will cause danger to child own integrity; (2) moral character, if the child does not have moral character, the child will always feel uncomfortable because of depression, fail to follow the environtment developement, distrack, unconfident and fail to behave in morality. Moral approachment put the importance of having moral goodness such as: honest; and (3) role moral, a person who has experience the life moral that can be made as a role model (Santrock, 2009:138).

Otherwise, emotional and social development at the age of pre-scholl based on the quality of child relationship with the neighbourhood, such ah the realtion with the family, and also the paly time quality with his/ her friends at the same age. The family child taking care type at the very early age of child in developing will influence the child personality in the future. A healthy emotion mother will able to manage the good relationship with her children. This is same as what Hendrick said "the quality of attachment between mother and child is additional important influence on socialization" (Hendrick, 1996:253). Teaching method to early children through five senses by John Comenius, the right cencoric by Pestalozzi, game by Froebel, culture by Vygotsky, and music by Montessori (Roopnarine, 2011:243244).

Based on these opinions above, it is concluded that early childhood is children from birth until the age of nine years who have unique and experienced of growth and development optimal in mental.

\section{Results and Discussion}

Based on careful assessment of Pedanda Baka story which is study of literature, we can discuss about:

\subsection{Character Education that Can be Educated Through Pedanda Baka Story Since Early Childhood}

Character education through Pedanda Baka story for young children is religious character. Religious character is trust to Ida Sang Hyang Widhi Wasa. In Hindu, religious character is explained in Panca Sraddha, including believe in Karma Phala or believe in results of every human action. Breathing, heart beating and dream are karma (Cudamani, 1993:3-4). If we do well, we get good results, and vice versa. Religious character that can be found in Pedanda Baka story is killing of Pedanda Baka by the crab as results of Pedanda Bakas bad behavior. Pedanda Baka lied and killed all fishes in the lake. It showed that Pedanda Baka receive Prarabda Karma Phala, which means actions in this life will be 
received in this life too. Swami Sivananda said that the Karma is the number of series actions of this life or in the preceding births (Sivananda, 2003:77). Based on that thought, Balinese Hindu always attempt to do good. Parents can teach religious character by telling that Pedanda Baka's bad behavior was paid by its killing by the crab.Through this story, parents can teach children to do good things such as: being honest, shall not murder, believe in Ida Sang Hyang Widi Wasa and Karma Phala. Pedanda Baka's story is an appropriate medium to teach religious character. Religious teachings is abstract, it is hard to understand by children. This story can help us to teach children to understand religious teachings and acts according to it.

According to Spencer, religion is "believe to something eternal that is out of mind". Max Muller see religion as an effort to understand what cannot be understood, reveal what cannot be revealed, and a desire for something unlimited. According to M. Reville, "religion is determinant of human life, which is a bond that unites human mind with the mysterious mind that control the world and himself, and with the cause of peace when we bound with it" (Durkheim, 2011:49-56). According to Gollnick "Religious beliefs about human events such as a birth and death and the very purpose of life all influence what children think, say, and $d o$ "... (Eliason and Loa Jenkins, 2008:117). Religion represent technique of spirituality (Hull, 2009:601), but religion is not something that human can see. It needs to be approached by inner life through external media (Engebretson, 2009:655), and Piaget said that in the second stage (occuring from 7 or 8 until 13 years of age) concrete operational where religious thought of children focused on particular details of pictures and stories (Santrock, 2007:550). That is why religious character is very suitable if taught through Pendanda Baka story.

\subsection{Pedanda Baka Story as Media of Character Education since Early Childhood}

According to Shichida "right brain learn from sound" (Shichida, 2013:88), and Aamodt in Welcome to Your Child's Brain stated that, "young child focus on human voice" (Aamodt, 2014:8). Based on that theory, Pedanda Baka story is suitable to be media of character education for young children. Early childhood always need model in act, and in a story there a model as overview of human behavior. Social cognitive theoriests suggest that a good deal of our learning comes from observing and modeling what other people do. How Modeling Affect Behavior? Social cognitive theoriests have proposed that modeling has several effects: (1) Modeling teaches new behaviors. People can learn entirely new behavior by observing others perform them, (2) Modeling influences the frequency of previously learned behaviors. As note earlier, people are more likely to exhibit behaviors they've previously learned if they see others being reinforced for such behaviors that, (3) Modeling may encourage previously forbidden behaviors, and (4) Modeling increases the frequency of similar behaviors (Ormrod, 2014:125-127).

Character education for early childhood through Pedanda Baka story can be delivered by:

\section{A. Parents told story of Pedanda Baka to their child.}

Storytelling will increase attachment between parents and their child. According to Sandra Aamodt "in early childhood, warm parenting by mother is associated with selfcontrol ability", if young children can control themselves, they will have good character. Character education can be delivered through story. Jane Brook stated that "if warm parenting has been formed, parents can teach desirable 
habit (Brook, 2011:117). Parents can bond with their children through Pedanda Baka story and transfer character education according to the story. Sandra Aamodt says that behavior setting occurs in the midline structures of the brain, namely the hypothalamus, amygdala, and hippocampus, it also occur in the forebrain (frontal lobe), frontal lobe is responsible for choosing appropriate behavior based on the objectives and the local environment (Aamodt, 2014:14-15). Pedanda Baka story will trigger brain development, so religious character can be built. To teach character, parents and child should have emotional bond. According to Carter, "emotion is part of interaction between mother and son", and parents can built emotion while telling the story. Sandra Aamodt stated that, "at birth, baby's brain is not fully develop, but some parts of the brain are relatively develop including auditory and touch sense, therefore auditory and touch sense are the best way to connect with young child" (Aamodt, 2014:113). Through Pedanda Baka story, parents can teach religious character to their young child. Bruce said that children is more easily taught through story (Bruce 2013:116).

\section{B. Teacher told story of Pedanda Baka at school.}

Character education can be taught ot only at home, it can also taught at school. According to Garcia Coll and Szalacha, "school is the most important social influence beside family" (Brooks, 2011:148), school is the third world for young children after home and community, after they enter school age, early childhood is not only stay at home but interact with peoples at their community and at school, that is why to build good character, teacher has a responsibility to give character education to early childhood at school. To educate religious character to early childhood at school effectively, teacher can use story, because according to Bruce, children is easier to understand difficult idea if its delivered through story, it is a strong learning mechanism, at young age symbolic behavior is developed, and story is symbolic. Stories help to make abstract and intangible concept, becomes concrete and tangible (Bruce 2013:115). Based on Bruce's statement, Pedada Baka story should be used as a media of character education since early childhood, and school teachers should constantly tell Pedanda Baka story to children from an early age.

\section{Conclusions}

Storytelling is a traditional ancient Balinese culture; story can be used as a media to deliver character education since early childhood. Story telling can build warm relationship between parents and their early childhood, therefore character education can be transferred easily. Pedanda Baka story contains value of religious character; it tells that bad behavior will get punishment. Because has done evil kill all the fish found in the lake then pedanda baka get punishments were killed by crab. Character education through Pedanda Baka story can be delivered at home by parents to child since early childhood and at school by teacher for students. Character education can be given not only at home but also at school because during school age school is child's world. Through Pedanda Baka story the character education of religious to child since early childhood can be easily to done, because in the story be found figure that can become role model to child since early childhood in act.

\section{References}

Aamodt, Sandra dan Sam Wang. Welcome to Your Child's Brain. Jakarta: Gramedia Pustaka Utama, 2013.

Atmaja, I Made Nada et al., Etika Hindu. Surabaya: Paramita, 2010.

Beckley, Pat. Learning in Ealy Childhood. California: Thousand Oaks, 2012. 
Brooks Jane. The Process of Parenting. New York: McGraw-Hill, 2011.

Bruce, Tina, Early Childhood: A Guide for Students second Edition. California: Thousand Oaks, 2013

Cudamani. Karmaphala dan Reinkarnasi. Jakarta: Hanuman Sakti, 1993.

Damon, William. Bringing in A New Era in Character Education. Californea: Hoover institution Press, 2002.

Danim, Sudarwan dan H. Khairil. 2010. Pedagogi, Andragogi, dan Heutagogi. Bandung: Alfabeta,

Dewantara, KI Hajar. Pendidikan. Yogyakarta: Majelis Luhur Persatuan Taman Siswa, 2004.

Durkheim, Emile. Sejarah Bentuk-Bentuk Agama yang Paling Dasar terjemahan Inyiak Ridwan Muzir. Jogjakarta: IRCiSoD, 2011.

Eliason, Claudia and Loa Jenkins, A Pratical Guide to Early Childhood Curriculum Eighth Edition. New Jersey: Pearson, 2008.

Engebretson, Kathleen. International Handbooks of Religion and Education 1. Springer, 2009

Gotama, Anatta. Warta Hindu Dharma Edisi 484. Denpasar: Parisada Hindu Dharma Indonesia Pusat, 2007.

Hull, John M. International Handbooks of Religion and Education 1. Springer, 2009

Kontopodis, Michalis. Children, Development and Education. New York: Springer, 2011.

Koster, Joan Bouza. Growing Artists: Teahing the Arts to Young Children, Fifty Edition. United States: Wadsworth, 2012.
Lapsley, Daniel K and F. Clark Power. Character Psychology and Character Education. Indiana: University of Notre Dame, 2005.

Lickona, Thomas. Educating for Character Ed 1 terjemahan Juman Abdu Wamaungo. Jakarta: Bumi Aksara, 2012.

McElmeel, Sharron L. Character Education: A Book Guide for Teachers, Librarians, and Parents. Colorado: Libraries Unlimited, 2002.

Morrison, George S. Dasar-dasar Pendidikan Anak Usia Dini (PAUD) edisi 5, Alih Bahasa: Suci Ramadhona \& Apri Widiastuti. Jakarta: Indeks, 2012.

Nucci, Larry P and Darcia Narvaez. Handbook of Moral and Character Education. New York: Madison Ave, 2008.

Nutbrown Canthy and Peter Clough. Pendidikan Anak Usia Dini: Sejarah, Filosofi, dan Pengalaman. Yogyakarta: Pustaka Pelajar, 2015.

Ormrod, Jeanne. 2014. Human Learning Pearson New International Edition. USA: Pearson.

Roopnarine, Jaipaul L. dan James E. Johnson. Pendidikan Anak Usia Dini dalam Berbagai Pendekatan edisi kelima terjemahan Sari Narulita. Jakarta: Kencana Prenada Media, 2011.

Samani, Muchlas dan Hariyanto. Pendidikan Karakter. Bandung: Remaja Rosdakarya, 2012.

Santrock, John W. 2007. Children Ninth Edition. New York: McGraw-Hill

Sivananda, Sri Swami. Intisari Ajaran Hindu. Surabaya: Paramita, 2003.

Soegeng, Santoso. Pedoman Peningkatan Kompetensi Pendidikan Berbasis Karakter. Pusat Pengembangan Profesi 
Pendidik Kementerian Pendidikan Nasional, 2012.

Tilaar, H.A.R. Kekuasaan dan Pendidikan: Manajemen Pendidikan Nasional dalam Pusaran Kekuasaan. Jakarta: Rineka Cipta, 2009.

\section{Journal}

Correa, Julio E, Olga B. González, and Martha S. Weber. 1991. Story telling in families with children: A therapeutic approach to learning problems. Contemporary Family Therapy, Volume 13 (Issue 1), pp 33-59. http://link.springer.com/ article/10.1007/BF00892228

Gal, E, and others. 2005. Enhancing Social Communication Through Story-Telling Among High-Functioning Children with Autism. Lecture Notes in Computer
Science. 3814, pp 320-323._http:// link.springer.com/chapter/10.1007/ $11590323 \quad 43$

Lacasa, Pilar. 2013. Story Telling. Palgrave Macmillan's Digital Education and Learning, pp: 159-187. http://link.springer. com/chapter/10.1057/9781137312051_8

\section{Online}

http://www.tribunnews.com/video/2014/12/11/ newsvideo-anak-bunuh-orangtua-karenatak-dibelikan-motor

http://jogja.tribunnews.com/2016/10/18/siswasma-tegas-bunuh-teman-sekelas-karenadekati-sang-mantan-pacar

https://hello-pet.com/miris-anak-sd-sekarangbanyak-yang-membunuh-temannyasendiri-108929 